\title{
Erratum to: Fine-grained information extraction from German transthoracic echocardiography reports
}

\author{
Martin Toepfer ${ }^{1 *}$, Hamo Corovic ${ }^{2}$, Georg Fette ${ }^{1,2}$, Peter Klügl ${ }^{1,3}$, Stefan Störk ${ }^{2}$ and Frank Puppe
}

\begin{abstract}
After publication of the original article [1] it was brought to our attention that figures three and four had been interchanged on the website, meaning that they were then matched with the wrong figure legends. This has now been updated on the website.
\end{abstract}

\begin{abstract}
Author details
${ }^{1}$ Chair of Computer Science VI, University of Würzburg, Am Hubland, Würzburg D-97074, Germany. ${ }^{2}$ Comprehensive Heart Failure Center, University of Würzburg, Straubmühlweg 2a, Würzburg D-97078, Germany.

${ }^{3}$ Averbis GmbH, Tennenbacher Straße 11, Freiburg D-79106, Germany.
\end{abstract}

Received: 27 November 2015 Accepted: 27 November 2015

Published online: 03 December 2015

\section{Reference}

1. Toepfer M, Corovic H, Fette G, Klügl P, Störk S, Puppe F. Fine-grained information extraction from German transthoracic echocardiography reports. BMC Med Inform Decis Mak. 2015;15:91.

\footnotetext{
*Correspondence: martin.toepfer@uni-wuerzburg.de

${ }^{1}$ Chair of Computer Science VI, University of Würzburg, Am Hubland, Würzburg D-97074, Germany

Full list of author information is available at the end of the article
}

Submit your next manuscript to BioMed Central and we will help you at every step:

- We accept pre-submission inquiries

- Our selector tool helps you to find the most relevant journal

- We provide round the clock customer support

- Convenient online submission

- Thorough peer review

- Inclusion in PubMed and all major indexing services

- Maximum visibility for your research

Submit your manuscript at www.biomedcentral.com/submit 